\title{
ÖĞRETMEN GÖZÜYLE ÇOCUK DOSTU OKUL ${ }^{1}$
}

\author{
Child Friendly School from Teacher's \\ Perspective
}

Gönderim Tarihi: 13.01.2017

Kabul Tarihi: 11.12 .2017

\section{Aydan ORDU* \\ Fatma ÇOBANOĞLU \\ Zeynep AYVAZ-TUNCEL}

ÖZ: Çocuk hakları sözleşmesinde de belirtildiği üzere eğitim her çocuğun hakkıdır ve bu hakkın fırsat eşitliği ilkesi gözetilerek gerçekleştirilmesi gerekmektedir. Bu hakların eğitim süreçlerine ve okul ortamlarına yansıtılabilmesi için 2003-2004 eğitim-öğretim yılında MEB ve UNICEF işbirliği ile Çocuk Dostu Okul (ÇDO) çalışmaları başlatılmıştır. ÇDO, eğitimli öğretmenlerle yeterli kaynağın ve öğrenme için uygun fiziksel, duygusal ve sosyal koşulların sağlandığı; öğrencinin güvenliğine, sağlı̆̆ına ve cinsiyetine duyarlı ve demokratik katılımın önemsendiği bir çevreyi içerir. Bu düzenlemelerin gerçekleşmesinde öncelikle okul çalışanlarının ÇDO'ya ilişkin farkındalık geliştirmiş olması ve eğitimin paydaşları ile işbirliği içinde çalışmaları gerekmektedir. Bu araştırmada, öğretmenlerin çocuk dostu okulun özelliklerine ilişkin düşüncelerini ve farkındalıklarını belirlemek amacıyla olgubilim (fenomoloji) deseni kullanılmıştır. Araştırmanın ilk aşamasında 8 okul yöneticisi ve 17 öğretmen ile yüz yüze görüşmeler gerçekleştirilmiştir. Araştırmanın ikinci aşamasında ise iki açık uçlu sorunun yer aldığı form 62 öğretmen tarafından çevrimiçi ortamda doldurulmuştur. Görüşme ve yazılı formlardan elde edilen veriler doğrultusunda yapılan içerik analizi ile çocuk dostu okulların özellikleri kapsamlılık, etkililik, sağlıklı, güvenli ve koruyucu öğrenme ortamı, demokratik katılım olmak üzere dört tema altında toplanmıştır. Öğretmenlerin

\footnotetext{
${ }^{1} \mathrm{Bu}$ çalışma 2016 yılında Türkiye, Antalya'da düzenlenen I. Uluslararası Akademik Araştırmalar Kongresi'nde sözlü bildiri olarak sunulmuştur ve Pamukkale Üniversitesi Bilimsel Araştırma Projeleri (PAÜBAP) Koordinasyon Birimi tarafından desteklenmektedir.

* Yrd. Doç. Dr., Pamukkale Üniversitesi/Eğitim Fakültesi,/Eğitim Bilimleri Bölümü/Eğitim Yönetimi Anabilim Dalı, akursunoglu@gmail.com, ORCID ID: orcid.org/0000-0002-2068-7992

* Yrd. Doç. Dr., Pamukkale Üniversitesi/Eğitim Fakültesi,/Eğitim Bilimleri Bölümü/Eğitim Yönetimi Anabilim Dal1, fcobanoglu@pau.edu.tr, ORCID ID: orcid.org/0000-0002-3584-0814

*** Yrd. Doç. Dr., Pamukkale Üniversitesi/Eğitim Fakültesi/Eğitim Bilimleri Bölümü/Eğitim Programları ve Öğretim Anabilim Dalı, zatuncel@pau.edu.tr, ORCID ID: orcid.org/0000-0003-1817-9603
} 
çoğu okullarının çocuk dostu özelliklere sahip olmadığını belirtirken, büyük bir kısmı kısmen çocuk dostu olduğunu, çok azı ise çocuk dostu özelliklere sahip olduğunu belirtmiştir.

Anahtar Kelimeler: Çocuk Dostu Okul, Çocuk Hakları, Öğretmen Algısı.

ABSTRACT: As The Convention on the Rights of the Child declares, all children are entitled to the right to be educated by taking into consideration the gender equality. So as to adapt these rights to educational process and school environment, Child Friendly School (CFS) studies were started with the cooperation of Ministry of Education and UNICEF in 2003-2004 academic year. CFS provides an educational environment with trained teachers, adequate resources and appropriate physical, emotional and social conditions for learning; senses about safe, health and gender of children and pays attention to democratic participation. The main condition for actualizing these arrangements is the awareness of the school workers about CFS and cooperation with educational stakeholders. In this study, for determining the opinions and the awareness of the teachers about CFS's characteristics, phenomenology design was used. In first phase of the study, face-to-face interview data were collected from 8 administrators and 17 teachers. In second phase of the study, a form with two open-ended questions was filled online by 62 teachers. As a result of the content analysis of the data obtained from interviews and written forms, characteristics of childfriendly schools were collected under the themes of inclusiveness, effectiveness, a healthy, safe, and protective learning environment and democratic participation. While most teachers stated that their schools do not have child-friendly features, a large part of them said that their schools are partly child-friendly, and few teachers stated that their schools have child-friendly characteristics.

Keywords: Child Friendly School, Rights of the Child, Teacher's Perception.

\section{GİRiş}

Son yıllarda çocuk dostu olarak nitelendirilen çok sayıda kurum göze çarpmaktadır. Turizm, şehircilik, sağlık, gıda ve eğitim gibi çok farklı alanlarda hizmet veren bu kurumların, çocuk dostu olmak için politikalarında, süreçlerinde, programlarında ve bütçelerinde çocukların haklarına ve ihtiyaçlarına gereken önemi vermeye başladıkları görülmektedir.

Toplumların geleceklerini inşa etme misyonunu yüklenen ve bir ulusun sosyal ve ekonomik kalkınmasının öncelikli mekanizması olarak tanımlanan okulların da çocuk dostu olması zorunluluğu kaçınılmazdır. Özellikle Çocuk Hakları Sözleşmesi ve UNESCO'nun Herkes İçin Eğitim Bildirgesi gibi uluslararası belgeler bu gerçeği temellendirmektedir. Ayrıca, Dünya Sağlık Örgütü'nün çocukta bağlılık, bakım ve desteğe erişim vurgusu; UNICEF'in okul geliştirmeye 
yönelik çocuk-aile-toplum merkezli yaklaşımlara olan özel ilgisi ve özellikle dezavantajlı çocukların gelişiminde önemli bir rol oynayan okullara dikkat çeken etkili okul araştırmaları da bu görüşü güçlendirmektedir (Godfrey vd., 2012).

Çocuk dostu okul (ÇDO) ilkelerinin kökleri, eğitimin bir insan hakkı olarak kabul edildiği ve 58 üye ülkenin imzaladığı 1948 Evrensel İnsan Hakları Bildirgesine kadar dayanır. Çocuk Haklarına Dair Sözleşme (1989) de dört anahtar ilke ile insan haklarına dayalı eğitim düşüncesini güçlendirmiş ve genişletmiştir. Bu ilkeler: (1) Ayrımcılığın önlenmesi, (2) Çocuğun çıkarına en uygun şekilde davranma, (3) Çocuğun mümkün olduğunca en üst düzeyde yaşama, varlığını sürdürme ve gelişim hakkını kullanmasını sağlama, (4) Kendilerini etkileyen her türlü durum karşısında çocuğa kendisini ifade etme olanağı tanımadır. Burada vurgulanan öğrenmeye fırsat yaratan erişim; bilişsel ve duyuşsal gelişimi destekleyen kalite ve bireyin diline, kültürüne, dinine ve bakış açısına değer veren saygı, hak temelli eğitimin merkezi ve önemli ilkeleridir ve 1990'larda çocuğun bütüncül gelişimini sağlayacak okul arayışlarına ve çocuk dostu yaklaşımının yaratılmasına zemin hazırlamıştır (UNICEF, 2007).

ÇDO aslında çocuğun yararına çalışmaya teşvik eden basit bir modeldir. Çocuk dostu okullar eğitimli öğretmenlerin, yeterli kaynak ve öğrenme için uygun fiziksel, duygusal ve sosyal koşulların sağlandığl; güvenli, sağlıklı ve koruyucu bir çevreyi içerir. Çocuk dostu bir okulda çocukların hakları korunur ve sesleri duyurulur. Öğrenme ortamları çocukların öğrenebildiği, gelişebildiği; kimliklerine, ilgi ve ihtiyaçlarına saygı duyulan bir cennettir (UNICEF, 2012a).

ÇDO modeli kapsamlılığı, cinsiyete duyarlılığı, hoşgörüyü, kişiliğin ve saygınlığın güçlendirilmesini teşvik eder. Okulları çocuk dostu hale getirmek için tek bir yol yoktur, ülkeden ülkeye farklılık gösterebilir ancak her kültürde çocuk dostu bir okul; güvenli, sağlıklı ve bütünsel bir ortamda çocuk merkezli eğitimi teşvik eder. ÇDO, doğu Avrupa ülkelerinde genellikle aşağıdaki boyutları içerir (Clair, Miske ve Patel, 2012: 8,9):

Kapsamlılık, her çocuğun cinsiyet, fiziksel ve sosyal özellikler, eğitim durumu, duygusal sorunlar, dil veya özel ihtiyaçlar gözetilmeksizin yüksek kalitede bir eğitim almasını sağlar.

Etkililik, kaliteli öğrenme ve öğretimi teşvik eder; çocuk merkezlidir ve bireysel ihtiyaçlara göre düzenlenmiştir. Öğretimde aktif, işbirlikçi ve demokratik yöntemleri kullanır.

Sağllklı, güvenli ve koruyucu bir öğrenme ortamı, her bir çocuğun fiziksel ve psikolojik refahını sağlayarak ve bir çocuğun öğrenme hakkına engel olan sağlık ve güvenlik konularını ele alarak bütün çocukları göz önünde bulundurur. 
Demokratik katılım, eğitim sürecini ve ortamını ilgilendiren her türlü karar, okul ve toplum içerisindeki farklı görüşleri göz önünde bulundurmalı ve bu yönde alınmalıdır.

Cinsiyete duyarlılık, bütün kız ve erkek öğrencilerin, temel ve özgün ihtiyaçlarını karşılayan ve kadın-erkek ilişkisindeki güç dinamiğini ele alan bir öğrenme ortamına tam anlamıyla katılabilmeleri için eşit fırsatlara sahip olmalarını taahhüt eder. Cinsiyet önyargısı sergilemeyen insan hakları anlayışını destekleyen materyalleri ve öğrenme deneyimlerini sağlar.

Eğitim çabalarının ve okulların amacı yalnızca çocukları okula getirmek değil çocuğun okula kaydına, düzenli devamına ve öğrenme başarısına engel olabilecek her faktörü dikkate almak ve uzun dönemli çıtılara odaklanmak olmalıdır (Godfrey vd., 2012). Çocuklar, evlerinin ve içinde yaşadıkları toplumun farklı koşullarıyla şekillenmiş benzersiz kişilikleri ve geçmiş yaşantıları ile okula gelirler. Bu nedenle, okullar çocuk dostu olup her çocuğun benzersiz kişiliğine ve ihtiyaçlarına saygı duymalıdır. Fiziksel çevre, okuldaki duygusal ve sosyal atmosfer tüm çocukları kapsayıcı nitelikte ve öğretme-öğrenme süreci için uygun olmalıdır. Çocukların hakları korunmalı ve sesleri duyulmalıdır. Okul ve çevresi, çocuğun öğrenebileceği ve korunabileceği bir sığınak olmal1dir (UNICEF, 2009).

Sıralanan tüm bu özelliklerin okul ortamlarında ve eğitim süreçlerinde yaşanan gerçekler haline gelmesi için MEB ve UNICEF iş birliği ile 2003-2004 eğitim öğretim yılında 25 ilköğretim okulunda ÇDO çalışmaları başlatılmıştır. Bu kapsamda, ilköğretim okulu yönetim ve eğitim personelinde, hak tabanlı eğitim kapasitesi geliştirme ve bunu destekleyen okul mekanizmaları kurmaya, bunların destekleyici eğitim ve dokümanlarını sağlamaya ilişkin bir dizi çalışma yürütülmüştür. 2005-2007 yılları arasında ÇDO uygulamaları Türkiye genelinde 326 ilköğretim okulunda uygulanmış ancak tüm ilköğretim okullarında niteliğin arttırılması hedefi doğrultusunda süreç içerisinde bu çalışma ulusal bir program olarak İlköğretim Kurumları Standartları'na, 2014 yılında da Kurum Standartları'na dönüştürülmüştür. Bu kapsamda ÇDO dâhilindeki tüm hak tabanlı eğitim anlayışı ve çocuk hakları Kurum Standartları'na yansıtılmıştır (MEB \& UNICEF, 2015). Tamamlanan bu yasal düzenlemeye rağmen öğretmenlerin "çocuk dostu" olmak konusundaki düşünceleri ve farkındalıkları da tüm okul süreçlerinde olduğu gibi ÇDO olma konusunda da anahtar unsurlardan biridir ve bu araştırmanın da temelini oluşturmaktadır. Osher, Kelly, Tolani-Brown, Shors ve Chen (2009) altı ülkeden elde ettikleri bulgular sonucunda, öğretmen niteliklerinin ÇDO uygulamalarının başarısında önemli bir yere sahip olduğuna dikkat çekmişlerdir. Yurt dışında yapılan araştırmalar incelendiğinde az sayıda da olsa, ÇDO ile ilgili çalışmaya (Bredenberg ve He- 
eyit, 2004; Chabbott, 2004; Clair vd., 2012; Hegde ve Shetty, 2008; Leino, 2011; Orkodashvili, 2013; Reimer, 2012; Weshah, Al-Faori ve Sakal, 2012) rastlanmıştır. Ancak ülkemizde ÇDO'ya ilişkin bir çalışmaya rastlanamamıştır. Araştırmanın bu anlamda ilk olması nedeniyle de literatüre katkıda bulunacağı düşünülmektedir. Bu araştırmada yanıtı aranan sorular; (1) Öğretmenlere göre, ÇDO'nun sahip olması gereken özellikler nelerdir? (2) Öğretmenlerin çalıştıkları okulların çocuk dostu özelliklere sahip olma durumu nedir? biçimindedir.

\section{YÖNTEM}

\section{Araştırmanın Modeli}

Bu çalışmada, öğretmenlerin ÇDO'ya ilişkin algılarının belirlenmesi için nitel araştırma desenlerinden olgubilim (fenomoloji) kullanılması uygun görülmüştür. Olgubilim araştırmalar, farkında olduğumuz ancak derinlemesine ve ayrıntılı bir anlayışa sahip olmadığımız olgulara odaklanır ve birkaç kişinin bir olgu ya da kavramla ilgili deneyimlerinin ortak anlamını tanımlar (Creswell, 2013: 77; Yıldırım ve Şimşek, 2005: 72).

\section{Çalışma Grubu}

Araştırmanın çalışma grubu iki aşamada belirlenmiştir. Birinci aşamada Denizli merkez ilçelerindeki ortaokullar, müfettiş görüşleri doğrultusunda, gözlenen sosyo ekonomik düzeyleri açısından alt, orta ve üst olmak üzere üç gruba ayrılmıştır. Maksimum çeşitlilik örneklemesi dikkate alınarak her bir gruptan üçer okul seçkisiz olarak araştırma kapsamına alınmıştır. Belirlenen okullarda görüşme yapma konusunda gönüllü ve uygun olan öğretmen ve yöneticiler araştırmanın birinci aşama çalışma grubunu oluşturmaktadır. Tablo 1 'de birinci aşama çalışma grubunun özellikleri verilmiştir.

Tablo 1: Çalışma Grubunun Özellikleri (Birinci Aşama)

\begin{tabular}{llc}
\hline Kod & Görev & Yönetici Sayısı \\
\hline $\mathrm{M}$ & Müdür & 6 \\
\hline $\mathrm{M}$ & Müdür yardımcısı & 2 \\
\hline & Toplam & 8 \\
\hline Kod & Branș & Öğretmen Sayısı \\
\hline GÖ & Fen Bilgisi & 5 \\
\hline GÖ & Sosyal Bilgiler & 3 \\
\hline GÖ & Matematik & 3 \\
\hline GÖ & Türkçe & 2 \\
\hline GÖ & İngilizce & 2 \\
\hline GÖ & Bilişim Teknolojileri & 1 \\
\hline GÖ & Müzik & 1 \\
\hline & Toplam & 17 \\
\hline
\end{tabular}


Birinci aşamada sekiz yönetici ve 17 öğretmen ile yüz yüze görüşmeler yapılmiştır. Görüşmelerden elde edilen veriler doğrultusunda, daha fazla öğretmenin ÇDO'ya ilişkin algısını belirleyebilmek amacıyla bir form oluşturulmuştur. Kolay ulaşılabilir durum örneklemesi yoluyla, çevrimiçi ortamdaki form, branşa ve okul düzeyine bakılmaksızın öğretmenlere gönderilmiştir. Formu yanıtlayan 62 öğretmen, araştırmanın ikinci aşama çalışma grubunu oluşturmuştur.

Tablo 2: Çalışma Grubunun Özellikleri (İkinci Aşama)

\begin{tabular}{lll}
\hline Kod & Branş & Öğretmen Sayısı \\
\hline YÖ & Sını öğretmeni & 24 \\
\hline YÖ & Matematik & 7 \\
\hline YÖ & Özel eğitim & 5 \\
\hline YÖ & Bilişim teknolojileri & 4 \\
\hline YÖ & Teknoloji tasarım & 4 \\
\hline YÖ & İngilizce & 3 \\
\hline YÖ & Sosyal bilgiler & 3 \\
\hline YÖ & Türkçe & 3 \\
\hline YÖ & Fen bilimleri & 2 \\
\hline YÖ & Beden eğitimi & 2 \\
\hline YÖ & Rehber öğretmen & 2 \\
\hline YÖ & Diğer & 3 \\
\hline & Toplam & 62 \\
\hline
\end{tabular}

Araştırma kapsamında, birinci ve ikinci aşama çalışma gruplarında yer alan toplam 87 öğretmenin görüşüne başvurulmuştur.

\section{Veri Toplama Aracı}

Bu araştırmada veri toplamak için iki ayrı form geliştirilmiştir. Öğretmenlerin ÇDO'ya ilişkin algılarını belirlemek amacıyla yüz yüze görüşmelerde kullanılmak üzere "görüşme formu" hazırlanmıştır. Literatüre dayalı olarak belirlenen soru, uzman görüşleri doğrultusunda düzenlenmiş ve denenerek son hali verilmiştir. Bu görüşme formu birinci aşama olarak nitelenen çalışma grubuna uygulanmış ve "Bir okulun çocuk dostu olabilmesi için hangi özelliklere sahip olması gerekir?" sorusuna yanıt aranmıştır.

Ayrıca, araştırmada yüz yüze görüşmelerde elde edilen veriler dikkate alınarak ikinci aşama çalışma grubuna uygulanmak üzere iki açık uçlu sorunun yer aldığ 1 "yazılı form" düzenlenmiştir. Bu formda öğretmenlerin ÇDO'ya ilişkin algılarını belirlemenin yanı sıra, öğretmenlerden çalıştıkları okulu ÇDO özellikleri açısından değerlendirmeleri istenmiştir. Bu bağlamda yazılı formda “ Bir okulun çocuk dostu olabilmesi için hangi özelliklere sahip olması gerekir?" ve "Çocuk dostu okul özelliklerine sahip olması açısından kendi çalıştığınız 
okulu değerlendirirseniz neler söyleyebilirsiniz?" soruları yer almıştır.

\section{Verilerin Toplanması}

Araştırmanın birinci aşamasında yer alan yönetici ve öğretmenlerle yüz yüze görüşmeler yapılmış ve ses kayıt cihazı kullanılarak veriler kaydedilmiştir. Araştırmanın ikinci aşamasında ise, öğretmen görüşlerini belirlemeye dönük hazırlanan ve açık uçlu sorulardan oluşan form, çevrimiçi ortamda öğretmenler tarafından yanıtlanmıştır.

\section{Verilerin Analizi}

Öncelikle görüşme kayıtları yazıya aktarılarak ve çevrimiçi formdaki yanıtlar düzenlenerek veri seti oluşturulmuştur. Literatürde yer alan ÇDO'ya ilişkin boyutlar dikkate alınarak taslak kod listesi hazırlanmış ve veri seti üzerinde içerik analizi yapılmıştır. Analiz sonucunda belirlenen kodlar alanyazında yer alan temalar altında düzenlenmiştir. Tema - kod ilişkisi düzenlenirken içsel benzeşiklik - dışsal ayrışıklık özellikleri dikkate alınmıştır. Temalar çerçevesinde veri seti tekrar gözden geçirilerek tema - kod ilişkisine son hali verilmiştir. İlgili temayı ve kodları yansıtacak doğrudan alıntılara yer verilerek araştırma raporlaştırılmıştır.

Araştırmanın iç geçerliğini sağlamak için farklı veri kaynakları kullanılmıştır. Yüz yüze görüşme yapılarak derinlemesine bilgi elde edilirken, yazılı form yoluyla da farklı kişilerin görüşleri belirlenmiştir. Farklı veri kaynaklarından aynı konu hakkında veri toplanarak gerçek algının ne olduğu incelenmiştir. Dış geçerliğini sağlamaya yönelik, araştırmanın verileri ayrıntılı bir biçimde betimlenerek okuyucuya sunulmaya çalışılmıştır. Bu amaçla da görüşmelerden doğrudan alıntılar yapılmıştır. Araştırmanın iç güvenirliğini (tutarlık) sağlamak için, veri seti iki ayrı araştırmacı tarafından kodlanmıştır Her iki araştırmacının da aynı kodu kullandığı durumlar görüş birliği, farklı kodu kullandığ1 durumlar ise görüş ayrılığı olarak değerlendirilmiştir. [Görüş birliği / (Görüş birliği + Görüş ayrılığı) x 100] formülü kullanılarak (Miles ve Huberman, 1994) güvenirlik katsayısı \% 95.4 bulunmuştur. Dış güvenirliği sağlamak için ise, araştırmacılar, araştırma sürecindeki ses kayıtları, yazılı dokümanlar, kodlamalar ve diğer tüm rapor ve analizleri gerektiğinde teyit incelemesine sunmak üzere saklamaktadır.

\section{BULGULAR}

Araştırmadan elde edilen bulgular doğrultusunda iki temel soruya yanıt aranmış, veriler "ÇDO özellikleri" ve "okulların çocuk dostu özelliklere sahip olma durumu" başlıkları altında raporlaştırılmıştır. 


\section{ÇDO Özellikleri}

Araştırmanın amacı doğrultusunda öğretmenlere ilk olarak, ÇDO'nun hangi özelliklere sahip olması gerektiği sorulmuştur. Görüşme ve yazılı formlardan elde edilen veriler doğrultusunda yapılan içerik analizi ile ÇDO'nun özellikleri dört tema (kapsamlılık, etkililik, sağlıklı, güvenli ve koruyucu öğrenme ortamı, demokratik katılım) altında toplanmıştır.

\section{Kapsamlilık}

Tablo 3' te görüldügü gibi bu tema rehberlik ve ayrımcı olmama şeklinde iki koddan oluşmaktadır.

Tablo 3: Kapsamlılık Temasına İlişkin Kod-Frekans Tablosu

\begin{tabular}{ll}
\hline Kodlar & f \\
\hline Rehberlik & 4 \\
\hline Ayrımcı olmama & 1 \\
\hline
\end{tabular}

ÇDO'lar, her çocuğun cinsiyeti, ırkı, dini ve dili gibi farklılıklarının yanı sıra, duygusal sorunlarını ve özel ihtiyaçlarını da gözeterek yüksek kalitede bir eğitim almasını sağlar. Bu bağlamda, öğretmenler ÇDO'da, her öğrenciye farklılık gözetilmeksizin duygusal sorunlarına yönelik rehberlik yapılması gerektiğini belirtmiştir. Bu konuda GÖ 15 görüşlerini “...O açıdan çocuklarla iyi ilişki içerisinde olduğunu düşünüyorum çoğumuzun yani manevi anlamda da neye ihtiyacl varsa paylaşımda bulunabiliyorlar ya da ailede olan bir sorun olduğunda gelip anlatabiliyorlar. Bunu paylaşabiliyorlar. O açıdan hani çocuk dostu deyince maddi manevi anlamda ihtiyaçlarm bize rahatlıkla dile getirmeleri bizim de elimizden geldiğince onlara o imkânları sunmamız..." şeklinde belirtmiştir. ÇDO'da olması gereken özelliklere ilişkin ayrımcı olmamaya vurgu yapan tek bir öğretmen olmuştur. YÖ 59 "Öğrenciler arasında ayrım yapmadan ilgi ve ihtiyaçlarına karşılık verebilmelidir." biçiminde fikirlerini dile getirmiştir.

\section{Etkililik}

Etkililik temasına ilişkin kod ve frekanslar tablo $4^{\prime}$ te verilmiştir. Öğrenci özelliklerini dikkate alma, ÇDO ile ilgili en çok vurgulanan özelliktir. Bu konuda YÖ49'un “Çocukların duygusal ve fiziksel özelliklerine göre düzenlenmiş bir okul çocuk dostu okuldur. Öğrenci ihtiyacına yönelik eğitim ortamı, ilgi istek ve yeteneklerin ayrıştırılarak buna yönelik müfredat çalışmasi; sadece akademik başarısının değil diğger yeteneklerinin de öğrenciyi bir iş sahibi yapabileceği üzerine yoğunlaşılmalıdır." ve M4'ün "...çocuk dostu okul onun hayatının kolaylaştı̆̆ı bir yerdir onun başarı ya da isteklerinin ya da kabiliyetlerinin geliştirilebileceği bir yerdir..." ifadeleri dikkate değer görüşlerden bazılarıdır. 
Tablo 4: Etkililik Temasına İlişkin Kod-Frekans Tablosu

\begin{tabular}{lc}
\hline Kodlar & f \\
\hline Öğrenci özelliklerini dikkate alma & 43 \\
\hline Okulun fiziksel özellikleri & 24 \\
\hline Okula karşı olumlu tutum & 24 \\
\hline Çok yönlülük & 18 \\
\hline Nitelikli personel & 8 \\
\hline Oyun yoluyla öğretim & 8 \\
\hline Ders ve teneffüs süresi & 5 \\
\hline Doğa sevgisi / çevreye duyarlılık & 5 \\
\hline Materyal ve kaynak sağlama & 5 \\
\hline Aktif öğrenme / yapılandırmacılık & 4 \\
\hline Nitelikli öğrenme çktıları/kaliteli eğitim & 3 \\
\hline Öğrenci sayısı & 3 \\
\hline Bireyselleştirilmiş öğretim & 2 \\
\hline Ö̆ğretmen özelliklerini geliştirme & 1 \\
\hline Yapıcı disiplin & 1 \\
\hline Öğrenciyi yönlendirme & 1 \\
\hline
\end{tabular}

Öğretmenlerin bu tema altında vurguladığı bir diğer özellik okulun fiziksel özelliklerdir. YÖ6 ÇDO'da olması gereken fiziksel özelliklere ilişkin görüşlerini “...Sosyal aktivite ortamlarmm olması, peyzaja sahip olması, koridorların farkl farklı renklerde olması, resimlerle süslenmesi sıcak bir ortam olması... bence çok güzel olurdu." şeklinde belirtmiştir. Öğretmenlerin çoğu, ÇDO'da öğrencilerin okula karşı olumlu tutuma sahip olmaları gerektiğini belirtmiştir. YÖ 23 “ ...Çocuk okulda kendisini en sevdiği ortamda yani evde, parkta veya oyun sahasindaki gibi mutlu hissetmelidir." ifadesi ile çocukların okulda mutlu olması gerektiğini vurgulamıştır. YÖ 51 ise "Öncelikle okul çocukların gözünde korku merkezi olmamalıdır. Çocuklar okula severek, isteyerek özleyerek gelmelidir..." şeklinde görüş bildirmiştir.

Etkililik teması altında en çok vurgulanan kodlardan biri de çok yönlülüktür. GÖ 1'in "...sadece akademik odakl olmamalı yani başarn sadece işte TEOG'ta şu kadar soru yaptı bu kadar bilmem ne yaptı olmamalı yani. Hem ahlaki hem de sosyal yönden de bu çocuklar güçlü olursa zaten..." ifadeleri de bunu yansıtmaktadır.

ÇDO'nun sahip olması gereken özelliklerden biri olan etkililik teması altında ayrica:

- YÖ 51'in "Personel ve yönetici arasında sıkı bir iletişim olmalı, öğretmen severek okula gelmeli. Yönetici lider olmalı liyakat sahibi olmalı ki düzen olsun." görüşleri nitelikli personeli,

- YÖ'1 in “...Çocuk dostluğu oyun oynarken kazanır. O yüzden okullarda e ğgitimi oyunlaştırarak verildiği takdirde çocuk okulu da dost olarak kabul etmiş olacaktır." görüşleri oyun yoluyla öğretimi, 
- M 8'in "Daha çok çocuklar dışarıda stres atmayı istiyor teneffüslerin uzun olması lazım biz burada sabahçı öğleciyiz onar dakika yetmiyor çünkü yani en az 20 dakika bir normal eğitimde 20 dakika teneffüs olması gerekli. Isşte hayal ettiğimiz böyle bir okul." görüşleri ders ve teneffüs süresini,

- YÖ 19'un "...çevreyi doğayı seven sevdiren okul, hedef kitlesi çocuk bile olsa insan olduğu için doğa dostu olarak kabul edilebilir..." görüşü doğa sevgisi - çevreye duyarlılığ

- YÖ 47 'nin “...derslerle ilgili dikkat çekici materyallerin olması bu materyallerin işlevsel olması da gerekmektedir..." görüşü materyal ve kaynak sağlamayı ve

- YÖ 43'ün “... Öğrenen odaklı eğitim veren çocukların ihtiyaçlarımı ön planda tutarak esnek program uygulayabilen okuldur. Hayatilik ve yaparak yaşayarak öğrenme temele alınmalı yapılandırmacı bir eğitim sunulmalıdır..." görüşü aktif öğrenme/ yapılandırmacılığı vurgulamaktadır.

\section{Sağlıklı, Güvenli ve Koruyucu Öğrenme Ortamı}

Sağlıklı güvenli ve koruyucu bir öğrenme ortamı teması altında yer alan kodlar tablo 5'te verilmiştir. Öğretmenler ÇDO'da sağlığa ve hijyene önem verilmesi gerektiğini belirtmiştir. Nitekim YÖ 51'in “... Să̆glı açısından tuvaletler, sinfflar, yerler vs. temiz ve hijyenik olmalıdır... her okulda sağlık görevlisi bulunmalı ve hemen müdahale edebilmelidir. Beslenme saati olmal ve bu öğretmenler gözetiminde gerçekleştirilmelidir..." şeklindeki görüşü bu durumu yansitmaktadır.

Tablo 5: Sağlıklı, Güvenli ve Koruyucu Öğrenme Ortamı Temasına İlişkin Kod-Frekans Tablosu

\begin{tabular}{ll}
\hline Kodlar & f \\
\hline Sağlığın korunması / hijyen & 9 \\
\hline Güvenliğin sağlanması & 8 \\
\hline Sağlık eğitimi & 1 \\
\hline
\end{tabular}

Ayrıca YÖ 9'un“Okul güvenilir olmalı. Sınıf içinde ya da dışında çocuğun başına herhangi bir olay gelmemeli..." ve YÖ 38'in " ... Çocuklar için gerekli güvenlik önlemleri alınmış olmalı." ifadelerinde de görüldüğ̈ü gibi öğretmenler okullarda güvenli bir ortamın olması gerektiğine dikkat çekmiştir.

Sağlık eğitimini vurgulayan tek bir öğretmen olmuştur. YÖ 27 «... să̆glk ve hijyen konusunda öğretici materyaller çocuk dostu okullarda olması gereken özelliklerden bazılarıdır.» ifadesi öğretici materyaller ile sağlık eğitimini vurgulamıştır. 


\section{Demokratik Katılım}

Tablo 6'da demokratik katılım teması altında yer alan kodlar görülmektedir.

Tablo 6: Demokratik Katılım Temasına İlişkin Kod-Frekans Tablosu

\begin{tabular}{lc}
\hline Kodlar & f \\
\hline Okul yaşamına çocuğun katılımı & 18 \\
\hline İletişim & 7 \\
\hline Aile eğitimi & 1 \\
\hline
\end{tabular}

Öğretmenlerin bu tema altında en çok vurguladıkları kod, çocuğun okul yaşamına katılması olmuştur. Bu kod altında dikkat çeken görüşlerden bazıları şunlardir:

“Okul kurullarında çocuklar yer almalıdır..."( YÖ 36)

"Çocuklara soru sorulabilir dikkate alınabilir. Çünkü çocuklar o zaman kendini önemsiyorlar öbür türlü çocuğa hiçbir şey sormuyorsun. Her şeye kendin karar veriyorsun kendi kararını uyguluyorsun çocuklar robot gibi oluyor geliyor gidiyor geliyor gidiyor. Ama şunu şöyle yapalım mı? Şunu yapalım mı dediğin zaman çocukların daha çok hoşuna gidiyor..." (GÖ 5)

"Sinıf gerekirse tuvaletin düzenlenmesi kütüphanenin düzenlenmesi sinıfın düzenlenmesi okulun düzenlemeleri tamamen çocuklara bırakılmalı yani onların tercihlerine bırakılmalı ki..." (M 7)

Öğretmenler demokratik katılım teması içerisinde iletişimden de söz etmişlerdir. YÖ 25 bu konuya ilişkin fikirlerini “...her türlü iletişim kanalların açık bırakarak demokratik bir ortam sağlayarak aile veli öğretmen üçgeninde çocukları stkıştırmak yerine yapıcı bir ortam să̆lamalıdır..." şeklinde belirtmiştir. GÖ 13 “... Çocuklarımız mesela gelmediği zaman muhakkak öğretmenlerimiz telefonla arar. Çocuğunuz neden gelmedi işte rahatsız mi veya veli öğretmene döner..." ; GÖ 16 ise "Bu konuda öğretmenlerle öğrencileri arasında tatl bir iletişim olmalı, en büyük muhtaç oldukları şey bence bilgiden öte sevgi. Veliler bu konuda eksik kalabiliyorlar. Yani idareciler ve öğretmenler tatlı bir iletişimle daha çocuk dostu bir okul oluşturabiliriz..." ifadeleri ile bu konuya dikkat çekmişlerdir.

Demokratik katılım teması altında bir öğretmen aile eğitiminden bahsetmiştir. YÖ 24 görüşlerini “...Velilere yönelik bilgilendirmeler yapılmalıdır her yaş grubun özelliklerini anlatan..." biçiminde dile getirmiştir.

\section{Okulların ÇDO Özelliklerine Sahip Olma Durumu}

Araştırmanın ikinci aşamasında öğretmenlere okullarının ÇDO özellikleri taşıyıp taşımadı̆̆ı sorulmuştur. Yazılı formlardan elde edilen veriler doğrultusunda bu konudaki öğretmen görüşleri üç kod altında toplanmıştır. Tablo 7'de 
de görüldüğü üzere öğretmenlerin çoğu okullarının çocuk dostu özelliklere sahip olmadığını ve büyük bir kısmı kısmen çocuk dostu olduğunu söylemektedir. Sadece sekiz öğretmen çalıştığı okulun çocuk dostu özelliklere sahip olduğunu belirtmiştir.

Tablo 7: Okulun ÇDO Özelliklerine Sahip Olma Durumuna İlişkin KodFrekans Tablosu

\begin{tabular}{lc}
\hline Kodlar & f \\
Çocuk dostu olmayan okul & 30 \\
Kismen çocuk dostu okul & 20 \\
Çocuk dostu okul & 8
\end{tabular}

Okullarının ÇDO özelliklerine sahip olmadığını belirten öğretmenlerin yazılı değerlendirmeleri incelendiğinde maddi imkânsızlıklar, okulun fiziksel özellikleri, okula karşı olumsuz tutum, ders saatleri, öğretmen yetersizliği, sosyal etkinliklerin yetersizliği, donanım eksikliği (materyal, kaynak...), eğitim sistemi (sınav odaklı) gibi etkenlerden bahsettikleri görülmüştür. Bu konuda dikkat çeken görüşlerden bazıları: "Dört duvardan ibaret..." (YÖ 13), "Deneme sınavına yönelik çalışıyoruz." (YÖ 16), "...Okulumuzun bulunduğu çevre itibariyle heterojen bir aile ve mahalle yapısına sahip olup, iletişim çemberi yönünden bağımsız bir yapıya sahiptir. Okulun maddi yönden imkânlardan yoksun oluşu çocuklara zengin öğrenme çevresi firsatı elde edememesine sebep olmaktadır. Bir kaynağın yetersiz ya da hiç olmayışı zincirleme iletişim problemine dönüşmekte ve çocuklar için yapılan etkinlik, aktivite ya da öğrenme alanları etkisiz kalmakta ve kalııllı̆ın önüne set çekmektedir." (YÖ 25), "...çünkü donanım eksikliği çok fazla sınıflarda bile panodan dahi yoksunluk varken okulun öğrenci dostu olduğu kısmı bana biraz uzak geldi." (YÖ 31).

Öğretmenlerin bir kısmı ise okullarının çocuk dostu özelliklere kısmen sahip olduğunu belirtmiştir. Kısmen kodu altında toplanan öğretmenlerin değerlendirmelerine göre okullarının çocuk dostu olan ve olmayan özellikleri sınıflandırılmıştır. Öğretmenler okula karşı olumlu tutum, okulun fiziksel özellikleri, sosyal etkinlikler, hijyen, öğrenci merkezlilik, farklılıklara saygı açısından okullarının olumlu özelliklere sahip olduğunu belirtmişlerdir. Veli katılımında yetersizlik, çalışanlar arasındaki tutarsızlık, güvenlik, öğretim yöntemleri, aşırı başarı odaklı personel, geleneksel öğretmenler, geleneksel yönetim anlayışı ise öğretmenlerin okullarında söz ettikleri olumsuz özelliklerdir. YÖ 24 bu konuya ilişkin görüşlerini “Okulumuzun fiziksel açıdan tuvalet, lavabo, sıra, dış görünümü olarak çocuklara uygun. Okul bahçesi küçük olduğu için oyunlarda alan sıkıntısı yaşanmakta. Geziler, piknikler, kermes, okul çayı gibi sosyal etkinlikler sürekli düzenlendiği için çocuklar okulu hayatın daha içinden görüyor ve benimsiyorlar. Sadece velilere çocuk eğitimi hakkında doğru davranış ve tutum konulu bilgilendirmeler eksik diyebilirim..." şeklinde ifade etmiştir. YÖ 38 de bu durumu "Okulumda 
güvenlik önlemleri her ne kadar iş sağh̆ğı ve güvenliği kurallarına uygun yapılsa da yeterli değil. Hijyen kurallarına uygun. Ĕ̆itim ortamlarının düzenlenmesi düzgün bir şekilde planlanmış ancak okul binalarının yerleşimi ve planlaması düzgün olmadığından sınıf yetersizliği yaşanmış bu sebeple bazı sınıflar bölünmüş ve küçülmüş bu da öğrenmeyi etkilemektedir. Okulumuzda çocukların ders dışındaki zamanların geçirebilecekleri bir dinlenme odası, spor alanları ve bahçede banklar bulunmakta ancak belirttiğim diğer sosyal imkanlar bulunmamakta" olarak belirtmiştir.

Kendi okullarının çocuk dostu olduğunu ifade eden öğretmenlerin görüşleri incelendiğinde, öğretmenlerin güvenlik, iletişim, akademik başarı ve demokratik ortama vurgu yaptıkları görülmüştür. Nitekim YÖ 9 bu konuya ilişkin görüşlerini "Güvenilir. İstediği öğretmeniyle rahat bir şekilde konuşabilir, derdini anlatabilir ve yardım görür. Okul başarısı yüksektir. Çocuk başarıyı tadar ve mutlu olur." şeklinde belirtmiştir.

\section{TARTIŞMA}

Bu araştırmada öğretmenlerin ÇDO özelliklerine ilişkin düşünceleri ve farkındalıkları belirlenmeye çalışılmıştır. Elde edilen bulgular doğrultusunda; öğretmen görüşlerine göre, ÇDO'nun özellikleri kapsamlılık, etkililik, sağlıklı, güvenli ve koruyucu bir öğrenme ortamı ve demokratik katılım olmak üzere dört tema altında toplanmıştır. Bu temalar literatürdeki boyutlarla uyuşmaktadır. Ancak literatür incelendiğinde, UNICEF tarafından ÇDO özelliklerinin kapsamlılık, etkililik, sağlıklı, güvenli ve koruyucu bir öğrenme ortamı, demokratik katılım ve cinsiyete duyarlık olmak üzere beş boyutta toplandığı görülmektedir (Chabbott, 2004; Clair vd., 2012). Elde edilen bulgular incelendiğinde öğretmenlerin, literatürde yer alan cinsiyete duyarlık boyutuna ilişkin görüş bildirmedikleri görülmektedir. Ayrıca kapsamlılık boyutuna çok fazla odaklanmadıkları sonucuna ulaşılmıştır. Okulların kapsayıcı olması, ayrımcı olmaması gerektiğine ilişkin sadece bir öğretmenin görüş bildirmesi dikkate değerdir. Buradan hareketle öğretmenlerin ÇDO' larda bulunması gereken özellikler arasında cinsiyete duyarlık ve kapsamlılık boyutlarını göz ardı ettikleri söylenebilir. Oysa ÇDO farklılıklar bazında ayrımcılığı ve kalıplaşmış yargıları reddeder. Özellikle de risk altındaki çocuklara ve ailelerine ücretsiz ve zorunlu, hesaplı, ulaşılabilir bir eğitimi vurgular. Farklılıklara saygı duyar ve bütün çocuklar için öğrenme garantisi verir (örneğin: kızlar, çalışan çocuklar, etnik azınlıkların çocukları ve HIV/AİDS hastası çocuklar, engelli çocuklar, istismar ve şiddet kurbanı çocuklar). Değişik koşulları ve çocukların ihtiyaçlarını (örneğin: cinsiyete, farklı sosyal sınıflara, etnik kökene ve yetenek düzeyine dayanan) yerine getirerek farklılıklara tepki verir. Okula devam ve başarıda cinsiyet eşitliğini teşvik eder. Kalıplaşmış önyargıları ortadan kaldırır. Kız dostu olanakları, programı, ders kitaplarını ve öğrenme-öğretme sürecini 
garanti eder. Diğerlerinin haklarına, itibarına ve eşitliğine saygı göstermeye cesaretlendirir (UNICEF, 2012b).

Öğretmenlerin ÇDO özellikleri ile en çok etkililik boyutunu ilişkilendirdikleri sonucuna ulaşılmıştır. Araştırma kapsamında ulaşılan bu tema altında öğretmenlerin en fazla vurguladıkları kod, "öğrenci özelliklerini dikkate alma" olmuştur. Öğretmenler, ÇDO'nun öğrenci özelliklerini dikkate alması gerektiğini düşünmektedirler. Ayrıca, okulun fiziksel özelliklerinin çocuk dostu olması, öğrencilerin okula yönelik olumlu tutum geliştirmeleri ve okulların çok yönlü olması gerektiği de en fazla vurgulanan özellikler arasındadır. Pepperl ve Lezotte (1999) bakımlı okulların, öğrenci başarısı ve davranışları üzerinde önemli bir etkiye sahip olduğunu; yıkık dökük, bakımsız okul binalarının öğrencilere hiç kimsenin okula önem vermediği mesajını verdiğini belirtmektedir (Akt. Harbaugh, 2005: 41). Bununla birlikte, bu tema altında öğretmenlerin öğretme-öğrenme sürecinin çocuk dostu olmasına ilişkin çok fazla görüş bildirmemiş olmaları dikkate değerdir. Çünkü UNICEF'in tanımlamalarında ÇDO'nun her bir öğrencinin gelişim düzeyine, yeteneklerine, öğrenme stiline uygun bireyselleştirilmiş öğretim ve aktif, işbirlikçi ve demokratik öğrenme yöntemleri ile kaliteli bir öğretimi ve öğrenme sürecini teşvik eden; çocukların neyi öğrenmeye ihtiyaç duydukların belirleyen ve onlara yardım eden okullar olması gerektiği vurgulanmaktadır (UNICEF, 2012b).

Öğretmen görüşlerine göre, ÇDO'da olması gereken bir diğer özellik sağlıklı, güvenli ve koruyucu öğrenme ortamıdır. Ancak, kodların frekansları dikkate alındığında öğretmenlerin bu temaya gerekli vurguyu yapmadığı söylenebilir. Bu tema altında öğretmenler en fazla, sağlığın korunması ve güvenliğe dikkat çekmişlerdir. Marsden (2005), öğretmenlerin okullarının güvenli ve düzenli bir çevreye sahip olup olmadığına yönelik algıları ile öğrenci başarısı arasındaki ilişkiyi incelediği çalışmasında, güvenli ve düzenli bir çevre sağlanmadan öğrencilerin öğrenmesini olumlu yönde etkilemenin mümkün olmadığını savunan bulgulara ulaşmıştır. Ayrıca, aşırı soğuk, aşırı sıcak, rutubetli, rahatsız edici öğrenme ortamları büyük olasılıkla öğrenme-öğretme sürecini etkileyecektir. Marzano (2003), öğretmenlerin ve öğrencilerin okulda kendilerini güvende hissetmedikleri zaman öğrenme ve öğretme için gereken psikolojik enerjiye sahip olamayacaklarını, güvenli ve düzenli bir çevrenin, akademik başarı için kritik öneminin olduğunu belirtmektedir.

Öğretmenlerin okul yaşamına çocuğun katılımını, ÇDO özelliği olarak gördükleri sonucuna ulaşılmıştır. Bu durum, ÇDO'nun sahip olması gereken demokratik katılım özelliğine işaret etmektedir. Perry'e (2009) göre, öğretme-öğrenme ve demokrasi arasındaki ilişki, demokratik çıktıların öncelikle eğitimle ilgili olduğunu göstermektedir. Örneğin yurttaşlık eğitimi, eleştirel düşünme, 
sınıf tartışmaları, öğrenci konseyleri öğrencilerin yetenek, değer, tutum ve davranışlarının gelişmesine katkıda bulunur. Bu nitelikler öğrencilerin aktif birer yurttaş olmasına yardım ederek demokratik toplumların da güçlenmesine hizmet eder. Benzer biçimde Davies vd. (2006, Akt. Tüzün ve Sarışık, 2015) de eğitim ortamlarında çocuğun görüşlerini özgürce ifade edebilmesi, görüşlerinin ciddiye alınması ve çocuğun kendini doğrudan etkileyen karar alma süreçlerine katılabilmesinin temel bir hak olduğu gibi aynı zamanda eğitim süreçlerini ve ortamlarını olumlu yönde dönüştüren bir süreç olduğunu belirtmektedir. Öğrenci katılımının anlamlı biçimde yaşama geçebildiği okullarda, gerek öğrencilerin öğrenme ve gelişim düzeylerinde, gerekse okul ve sınıf düzeyinde olumlu sonuçlar gözlemlenir.

Öğretmenlerin çocuk dostu özelliklere ilişkin algıları belirlenmeye çalışılırken aynı zamanda onlardan kendi çalıştıkları okulların bu özelliklere ne kadar sahip olduğunu da değerlendirmeleri istenmiştir. Elde edilen veriler doğrultusunda öğretmenlerin çoğunluğu çalıştıkları okulların çocuk dostu özelliklere sahip olmadığını ya da kısmen sahip olduğunu düşündükleri görülmektedir. Okullarının ÇDO özelliklerine sahip olmadı̆̆ını belirten öğretmenler, maddi imkânsızlıklar, okulun fiziksel özellikleri, okula karşı olumsuz tutum, ders saatleri, öğretmen yetersizliği, sosyal etkinliklerin yetersizliği, donanım eksikliği (materyal, kaynak...), eğitim sistemi (sınav odaklı) gibi etkenlerden söz etmişlerdir. Benzer bir biçimde, Şahin ve Çeper (2013)'ün yaptıkları araştırma sonucunda da okulların ilköğretim kurum standartları düzeyine ulaşılmamasının nedenlerinden bazıları; personel eksiği, eğitim-öğretim araç-gereçlerinin eksikliği, binaların spor salonları, çok amaçlı salonlar ve bahçe alanları açısından yetersizlikleri şeklinde belirtilmiştir.

Genel olarak bakıldığında öğretmenlerin ÇDO'ya ilişkin genel bir bakış açısına sahip oldukları söylenebilir. Ancak, cinsiyete duyarlılık, çocuk hakları, engelli öğrenciler, ailenin sosyal ve ekonomik durumu gibi çocukların ihtiyaçlarına ve farklılıklarına yönelik özelliklere değinilmemesi dikkat çekicidir. Bu bağlamda öğretmen ve yöneticilere, çocuk hakları, farklılıklar, cinsiyete duyarlık gibi konularda kurs ve seminerler verilerek ÇDO'nun tüm boyutlarına ilişkin farkındalık oluşması sağlanabilir. Aynı zamanda var olan okul meclisi, kurul ve komisyonların daha işlevsel hale getirilerek demokrasi bilincinin oluşumu da desteklenmelidir. Okulların fiziksel düzenlemeleri yapilırken, «Kurum Standartlarında» da yer aldığı gibi ÇDO özelliklerinin daha fazla dikkate alınması bu çabayı destekleyecektir. Bu araştırmanın sınırlılıklarına dayalı olarak, ÇDO'ya ilişkin paydaşların bakış açısına dayanan araştırmaların daha geniş bir örneklem, farklı okul türleri ve kademeleri üzerinde yapılmasının alana katkı sağlayacağı düşünülmektedir. 


\section{KAYNAKÇA}

Bredenberg, K. ve Heeyit, Y. (2004). The Child Friendly Schools Movement and Impacts on Children's Learning: Practical Applications in Cambodia. Working Papers: Expanded Basic Education Program, Phnom Penh, Cambodia.

Chabbott, C. (2004). UNICEF's Child--Friendly Schools Framework (A Desk Review). Prepared under Special Services Agreement No. PD/03/I/065, October 14, 2003.

Clair, N., Miske, S. ve Patel, D. (2012). Child Rights and Quality Education: Child-Friendly Schools in Central and Eastern Europe (CEE). European Education, 44(2), 5-22.

Creswell, J. W. (2013). Nitel Araştırma Yöntemleri (Bütün M, Demir SB, Çev. Ed.). Ankara: Siyasal Kitabevi.

Çocuk Haklarına Dair Sözleşme (1989). UNICEF, Türkiye. 30.12.2016 tarihinde http://www.unicefturk.org/public/uploads/files/UNICEF_ CocukHaklarinaDairSozlesme.pdf adresinden alınmıştır.

Godfrey, E. B., Osher, D., Williams, L. D., Wolf, S., Berg, J., Torrente, C., Spier, E. ve Aber, J. L. (2012). Cross-National Measurement of School Learning Environments: Creating Indicators for Evaluating UNICEF's Child Friendly Schools Initiative. Children and Youth Services Review, 34(3), 546-557.

Harbaugh, R. J.(2005). Examining The Correlates Of Effective Schools Present in an Intermediate School: A Case Study (Yayımlanmamış Doktora Tezi), Immaculate University, Pennsylvania.

Hegde, A. ve Shetty, A. (2008). Child Friendly School Initiative at Karkala Taluk, Karnataka. Indian Pediatrics, 45(5), 407.

Leino, M. (2011). The Child Friendly School: An Idea Versus Reality. Problems of Education in the 21st Century, 29.

Marsden, D. B. (2005). Relations between Teacher Perceptions of Safe And Orderly Environment and Student Achievement Among Ten Better Performing, High-Poverty Schools in One Southern California Elementary School District (Yayımlanmamış Doktora Tezi), Pepperdine University.

Marzano, R. J. (2003). Using Data: Two Wrongs and a Right. Educational Leadership, 56-60.

MEB ve UNICEF (2015). Okul Öncesi Ĕ̆itim Ve İlköğretim Kurumları Standartları Kılavuz Kitabı. 
Miles, M. B. ve Huberman, M. A. (1994). An Expanded Sourcebook Qualitative Data Analysis. London, Sage.

Orkodashvili, M. (2013). Quality Education through Child-Friendly Schools: Resource Allocation for the Protection of Children Rights. Revista Romaneasca Pentru Educatie Multidimensionala, 5 (1), 101-109.

Osher, D., Kelly, D. L., Tolani-Brown, N., Shors, L. ve Chen, C. S. (2009). UNICEF Child Friendly Schools Programming: Global Evaluation Final Report. Washington, DC, American Institutes for Research.

Perry, L. B. (2009). Conceptualizing Education Policy in Democratic Societies. Educational Policy, 23(3), 423-450.

Reimer, J. K. (2012). Local Negotiation of Globalised Educational Discourses: The Case of Child Friendly Schools in Rural Cambodia (Yayımlanmamış Doktora Tezi), University of British Columbia.

Şahin, S. ve Çeper, B. A. (2013). İlköğretim Kurumları Standartları (İKS) Etkililiği Üzerine. Elektronik Sosyal Bilimler Dergisi, 12 (46), 84-111.

Tüzün, I. ve Sarışık, Y. (2015). Türkiye'de Okullarda Çocuk Katılımı: Durum Analizi. İstanbul, İstanbul Bilgi Üniversitesi Yayınları.

UNICEF (2007). Human Rights-Based Approach to Education for All. 9 Ocak 2017 tarihindehttps://www.unicef.org/publications/files/A_Human_ Rights_Based_Approach_to_Education_for_All.pdf adresinden erişilmiştir.

UNICEF (2009). Her Çocuk İçin Nitelikli Ĕ̆gitim Hakkı Ve Çocuk Dostu Okullar. 15 Ağustos 2016 tarihinde http://www.unicef.org.tr/basinmerkezidetay. aspx?id=2094 adresinden erişilmiştir.

UNICEF (2012a). Child - Friendly Schooling Approach. 15 Ağustos 2016 tarihinde https://www.unicef.org/education/bege_61717.html, adresinden erişilmiştir.

UNICEF (2012b). Child Friendly Schools. 16 Aralı 2013 tarihinde https://www. unicef.org/lifeskills/index_7260.html adresinden erişilmiştir.

Weshah, H., Al-Faori, O. ve Sakal, R. (2012). Child-Friendly School Initiative in Jordan a Sharing Experience. College Student Journal, 46(4), 699-715.

Yıldırım, A. ve Şimşek, H. (2005). Sosyal Bilimlerde Nitel Araştırma Yöntemleri. Ankara, Seçkin Yayıncılık. 
